\title{
Blooming fitoplankton di perairan Kepulauan Seribu
}

\section{Phytoplankton blooming in waters of the Thousand Islands}

\author{
Mursalin $^{1 *}$, R. Zulmi ${ }^{2}$, M. D. Putra ${ }^{1}$, L. D. W. Handayani ${ }^{1}$, I. A. Nur ${ }^{1}$ \\ ${ }_{1}^{1}$ Pusat Penelitian Lingkungan Hidup, IPB University, Bogor, Indonesia \\ 2Departemen Manajemen Sumberdaya Perairan, Fakultas Perikanan dan Ilmu Kelautan, IPB University, \\ Bogor, Indonesia
}

\begin{abstract}
Abstrak
Fenomena terjadinya blooming fitoplankton sering terjadi di perairan Kepulauan Seribu (Teluk Jakarta). Pada tanggal 15 Oktober 2020, terjadi kembali blooming tersebut Oleh karena itu, dilakukan kajian ini untuk mengetahui jenis fitoplankton yang mengalami blooming di Teluk Jakarta. Real time sampling terhadap fitoplankton yang mengalami blooming dilakukan. Selanjutnya sampel langsung dianalisis di Laboratorium Produktivitas dan Lingkungan Perairan, IPB University. Parameter yang dianalisis adalah komposisi jenis fitoplankton dan kualitas air. Fitoplankton yang blooming adalah Trichodesmium. Blooming telah terjadi sejak lama dan berulang di perairan Kepulauan Seribu. Hal ini berkaitan erat dengan perubahan musim dan peningkatan kandungan unsur hara di perairan, khususnya nitrat dan ortofosfat, yang mendukung terjadinya pertumbuhan fitoplankton secara pesat (blooming).
\end{abstract}

Kata kunci: blooming, ortofosfat, nitrat, Trichodesmium

\begin{abstract}
.
The phenomenon of phytoplankton blooms often occurs in the waters of the Thousand Islands (Jakarta Bay). On October 15, 2020, the blooming occurred again. Therefore, this study was conducted to determine the types of phytoplankton that were blooming in Jakarta Bay. Real time sampling of the blooming phytoplankton was carried out. Furthermore, the samples were directly analysed at the Laboratory of Productivity and Aquatic Environment, IPB University. The parameters analysed were the composition of phytoplankton species and water quality. Phytoplankton underwent blooming was Trichodesmium. Blooming frequently occurred in the waters of the Thousand Islands. This is closely related to seasonal changes and increased nutrient content in the waters, especially nitrate and orthophosphate, which support the rapid growth of phytoplankton (blooming).
\end{abstract}

Key words: blooming, orthophosphate, nitrate, Trichodesmium

\section{PENDAHULUAN}

Perairan pesisir merupakan salah satu perairan yang produktif sebagai daerah asuhan dan daerah berkembang biak dari berbagai jenis nekton, plankton, bentos, dan flora (tumbuhan), baik berupa ikan, krustasea, moluska, gastropoda, mikroorganisme, dsb. Di sisi lain, perairan pesisir juga rawan mengalami pencemaran yang bersumber dari aktivitas daratan (land based pollution), serta aktivitas perairan pesisir dan offshore (sea based pollution).

Salah satu sumber pencemar yang banyak masuk ke perairan pesisir, khususnya di negara berkembang adalah runoff dari aktivitas domestik, perkotaan, dan pertanian yang membawa bahan pencemar. Di negara berkembang seperti Indonesia, limbah dari aktivitas-aktivitas tersebut pada umumnya belum diolah sebagaimana mestinya. Jika limbah tersebut masuk ke sungai dan perairan pesisir, maka bisa menimbulkan efek berupa pencemaran atau pengayaan unsur hara yang berlebihan di badan air (Al-Azri et al. 2015; Damar et al. 2021; Nasution et al. 2021).

\footnotetext{
${ }^{*}$ Korespondensi Penulis

Email : mursalin26@yahoo.com
} 
Pengayaan unsur hara berupa nitrogen $(\mathrm{N})$ dan fosfor $(\mathrm{P})$ mengakibatkan terjadinya eutrofikasi (penyuburan), bahkan menjadi terlalu subur. Eutrofikasi ini biasanya diikuti dengan pertumbuhan yang sangat pesat dari satu jenis fitoplankton yang dikenal dengan istilah blooming yang menyebabkan perairan menjadi berwarna karena terdapat jutaan sel fitoplankton yang tumbuh pesat. Blooming fitoplankton ini selain dipicu oleh adanya eutrofikasi juga distimulir oleh pergantian musim di laut yang merubah pola arus laut (Al-Azri et al. 2015; Sidabutar et al. 2016; Damar et al. 2021; Nasution et al. 2021).

Fenomena terjadinya blooming fitoplankton ini sering terjadi di Teluk Jakarta. Pada tanggal 15 Oktober 2020, Tim PT Pertamina Hulu Energi Offshore Northwest Java (PHE ONWJ) yang sedang berpatroli di sekitar Sumur Zulu sekitar Kepulauan Seribu menjumpai adanya kondisi perairan yang tidak normal berupa adanya garis atau lapisan berwarna kecokelatan di permukaan perairan (Gambar 1). Ketika kapal mendekat ke lapisan tersebut, tampak adanya gradasi warna dari coklat ke merah pada bagian lapisan bawah dari permukaan dan tercium aroma busuk seperti tanaman mati. Dengan latar belakang tersebut, dilakukanlah kajian ini untuk mengetahui jenis fitoplankton yang mengalami blooming di perairan Kepulauan Seribu, Teluk Jakarta.
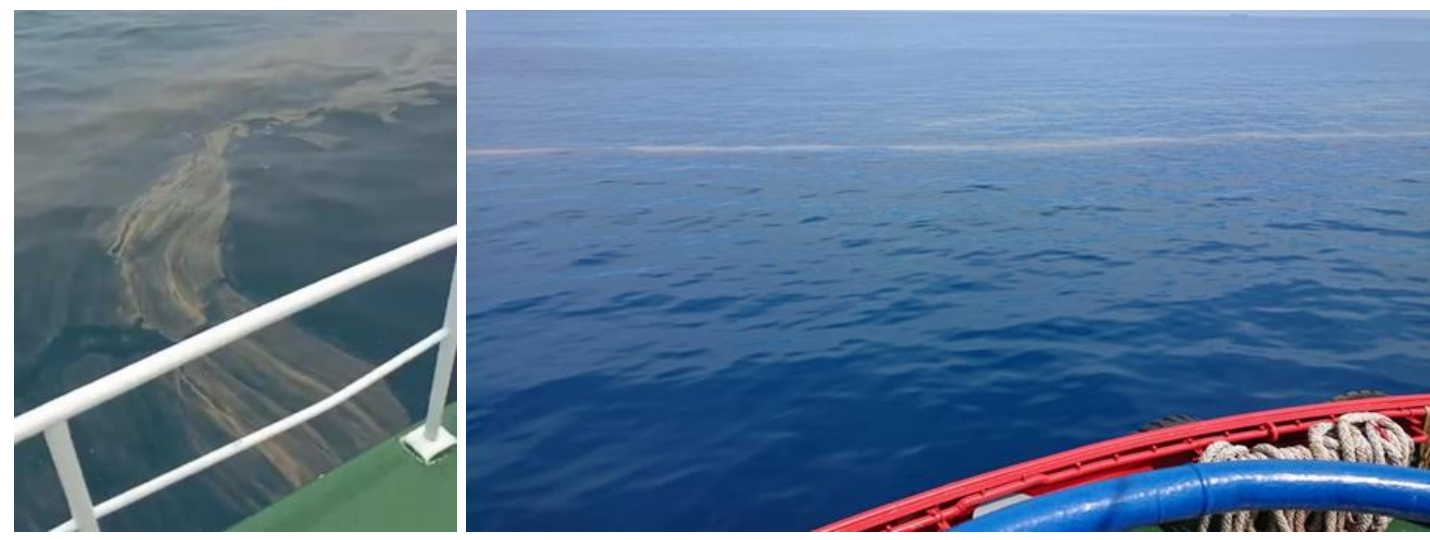

Gambar 1. Kondisi perairan laut di sekitar Sumur Zulu, sekitar Kepulauan Seribu.

\section{METODOLOGI}

Menindaklanjuti adanya permukaan air laut yang berwarna, dilakukanlah real time sampling air laut untuk analisis lebih lanjut di laboratorium dengan parameter uji berupa fitoplankton dan kualitas air. Lokasi pengambilan sampel sebanyak 15 titik, secara umum berada di sekitar Sumur Zulu (lokasi 1) yang terletak 15-25 Km arah timur laut dari Pulau Tondan Timur, lokasi 2 berada di 4 $\mathrm{Km}$ arah tenggara Pulau Harapan, lokasi 8 berada pada jarak $2 \mathrm{Km}$ arah barat daya dari Pulau Kotok Besar. Koordinat lokasi sampling disajikan pada Tabel 1, sedangkan peta sebaran lokasinya disampaikan melalui Gambar 2. 
Tabel 1. Lokasi dan waktu pengambilan sampel.

\begin{tabular}{clccc}
\hline \multirow{2}{*}{ Lokasi } & \multirow{2}{*}{ Kapal pengambil sampel } & \multicolumn{2}{c}{ Koordinat } & \multirow{2}{*}{ Tanggal sampling } \\
\cline { 3 - 4 } & & South & East & \\
\hline 1 & Royal King Ali, area Zulu & $05^{\circ} 32,050^{\prime}$ & $106^{\circ} 43,350^{\prime}$ & 16 Oktober 2020 \\
2 & Royal King Ali & $05^{\circ} 40,125^{\prime}$ & $106^{\circ} 36,899^{\prime}$ & 15 Oktober 2020 \\
3 & CB Pannarine1 & $05^{\circ} 32,290^{\prime}$ & $106^{\circ} 47,460^{\prime}$ & 16 Oktober 2020 \\
4 & U SV. FulMar & $05^{\circ} 31,266^{\prime}$ & $106^{\circ} 46,121^{\prime}$ & 16 Oktober 2020 \\
5 & Sv. Stella 28 (Area poin J) & $05^{\circ} 31^{\prime} 193^{\prime \prime}$ & $106^{\circ} 46^{\prime} 169^{\prime \prime}$ & 16 Oktober 2020 \\
6 & Sv. Stella 28 (oil area 1) & $05^{\circ} 28^{\prime} 604^{\prime \prime}$ & $106^{\circ} 39^{\prime} 629^{\prime \prime}$ & 16 Oktober 2020 \\
7 & Sv. Stella 28 & $05^{\circ} 33^{\prime} 523^{\prime \prime}$ & $106^{\circ} 44^{\prime} 064^{\prime \prime}$ & 16 Oktober 2020 \\
8 & SV. Fulmar & $05^{\circ} 42^{\prime} 250^{\prime \prime}$ & $106^{\circ} 30^{\prime} 680^{\prime \prime}$ & 16 Oktober 2020 \\
9 & PM-1 & $05^{\circ} 48,563^{\prime}$ & $106^{\circ} 37,894^{\prime}$ & 21 Oktober 2020 \\
10 & AL-10 & $05^{\circ} 30,005^{\prime}$ & $106^{\circ} 41,172^{\prime}$ & 21 Oktober 2020 \\
11 & PM-1 & $05^{\circ} 36,001^{\prime}$ & $106^{\circ} 48,740^{\prime}$ & 21 Oktober 2020 \\
12 & PM-1 & $05^{\circ} 36.001^{\prime}$ & $106^{\circ} 48,740^{\prime}$ & 21 Oktober 2020 \\
13 & PM-1 & $05^{\circ} 36.001^{\prime}$ & $106^{\circ} 48,740^{\prime}$ & 21 Oktober 2020 \\
14 & PB Tumenggung & $05^{\circ} 35^{\prime} 451^{\prime \prime}$ & $106^{\circ} 37^{\prime} 176^{\prime \prime}$ & 21 Oktober 2020 \\
15 & Anis Pateka 5401 & $05^{\circ} 46^{\prime} 920^{\prime \prime}$ & $107^{\circ} 01^{\prime} 943^{\prime \prime}$ & 21 Oktober 2020 \\
\hline
\end{tabular}

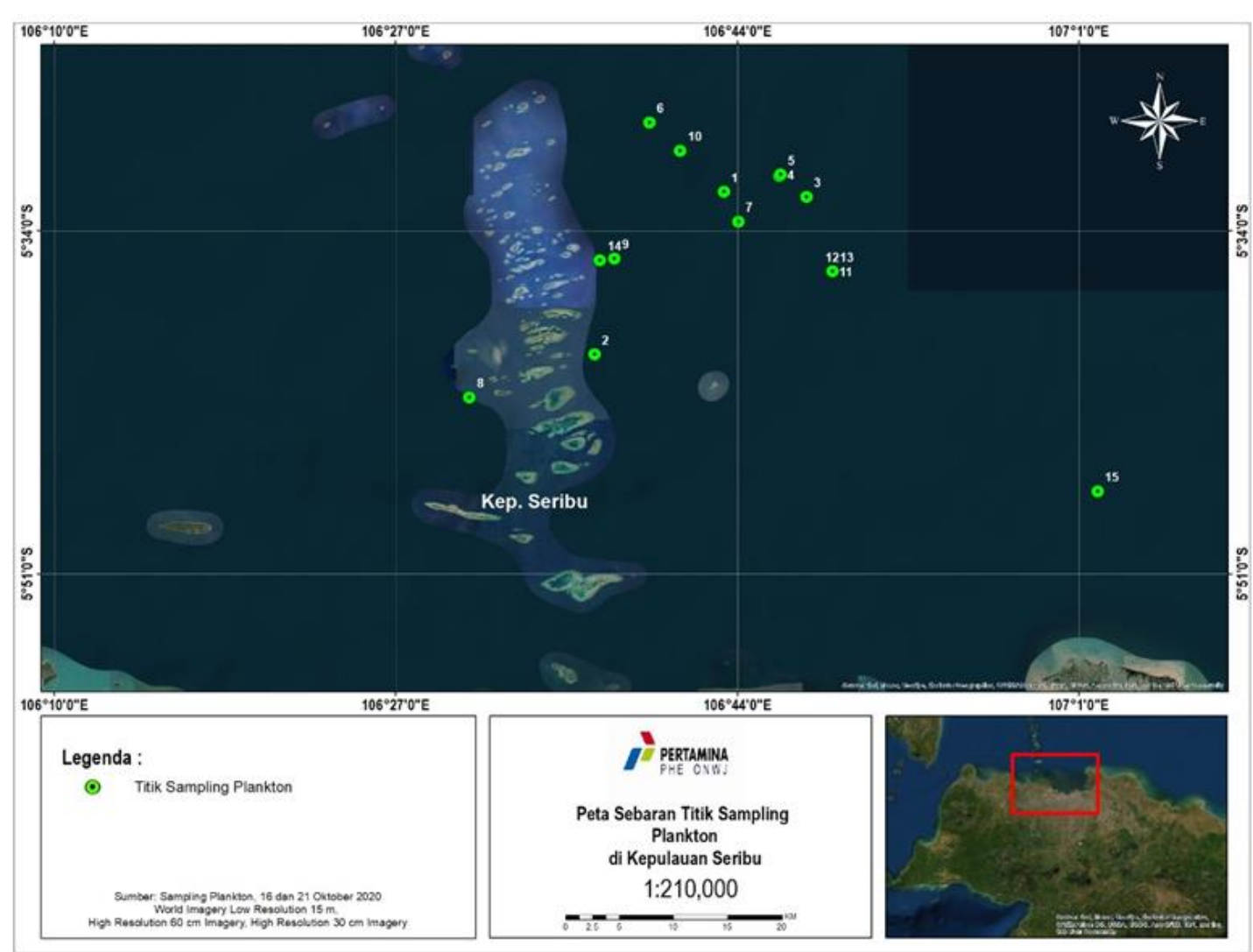

Gambar 2. Sebaran lokasi pengambilan sampel. 
Sampel langsung dianalisis di Laboratorium Produktivitas dan Lingkungan Perairan, IPB University. Parameter yang dianalisis adalah komposisi jenis fitoplankton dan kualitas air. Untuk fitoplankton dianalisis kelimpahan, keragaman, keseragaman, dan dominansi. Sementara untuk kualitas air, baku mutu kualitas air yang diacu adalah KepMenLH Nomor 51 Tahun 2004 tentang Baku Mutu Air Laut untuk Biota Laut, karena kejadiannya terjadi sebelum munculnya PP Nomor 22 tahun 2021 tentang Penyelenggaraan Perlindungan dan Pengelolaan Lingkungan Hidup.

\section{HASIL DAN PEMBAHASAN}

Sampel yang semula secara visual terlihat berwarna kecokelatan, setelah dimasukkan ke dalam wadah memiliki warna dan kondisi fisik yang beragam, mulai dari hijau, coklat, hingga merah dengan kondisi fisik seperti lumpur dan berlendir (Gambar 3).

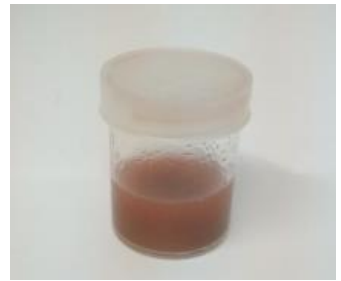

1. Area Zulu

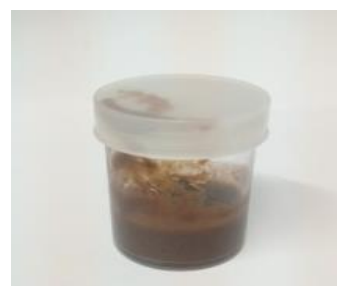

4. U SV. FulMar

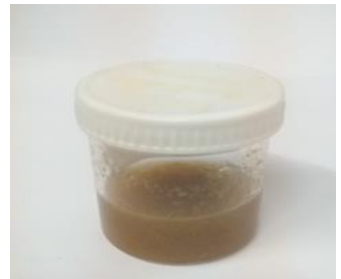

7. Sv. Stella 28

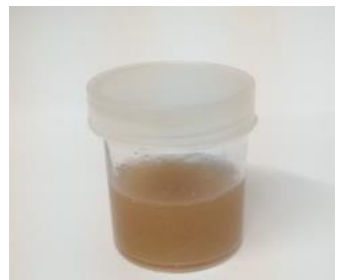

2. Royal King Ali

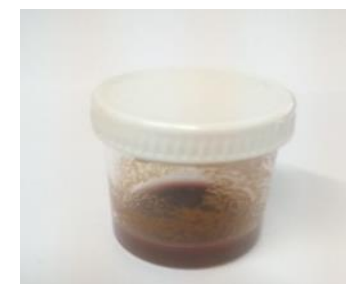

5. Sv. Stella 28 (Area poin J)

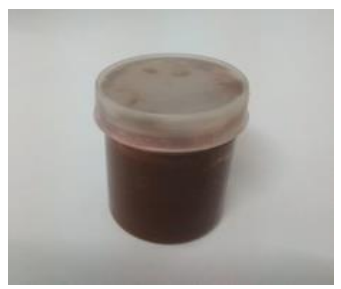

8. Kapal FulMar

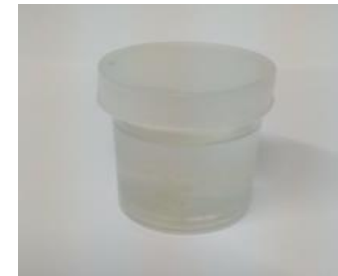

3. CB. Pannarine 1

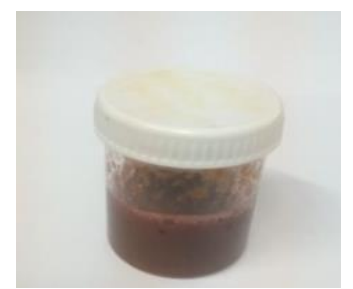

6. Sv. Stella 28 (oil area 1 )

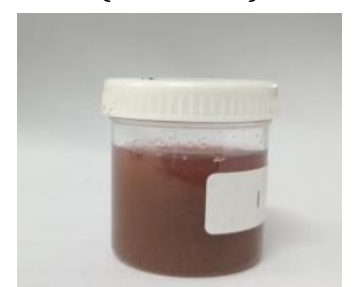

9. PM-1 


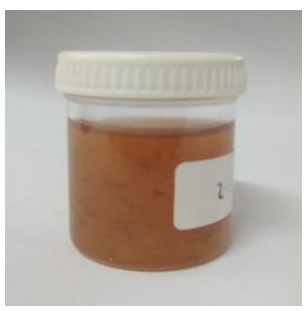

10. $\mathrm{AL}-10$

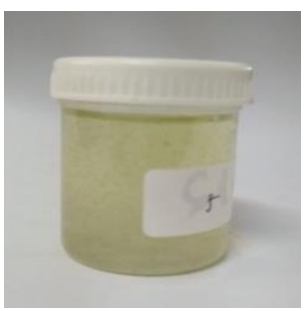

13. $\mathrm{PM}-1$

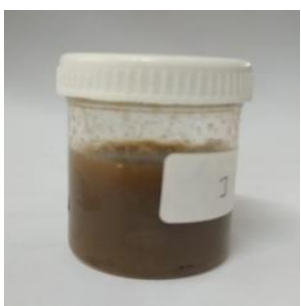

11. PM-1

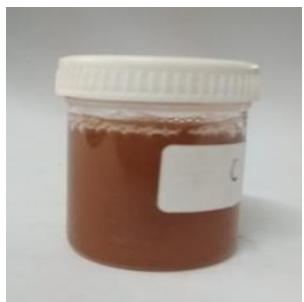

14. PB Tumenggung

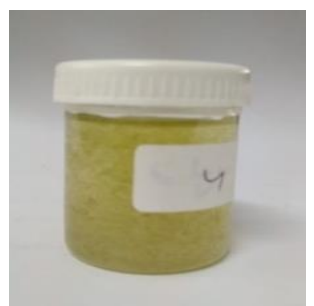

12. $\mathrm{PM}-1$

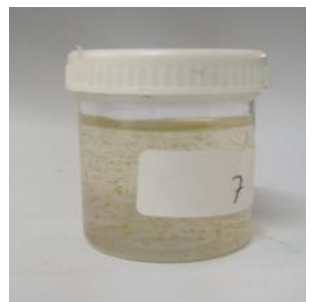

15. Anis Pateka 5401

Gambar 3. Kondisi sampel yang diambil dari setiap lokasi sampling.

Berdasarkan hasil analisis laboratorium terhadap fitoplankton (Tabel 2), diketahui bahwa seluruh lokasi sampling memiliki kelimpahan fitoplankton yang sangat tinggi dari genus Trichodesmium sp. (anggota Kelas Cyanophyceae) yaitu sejumlah 49.920.000 hingga 58.464.000.000 sel/liter. Genus Chaetoceros sp. (anggota Kelas Bacillariophyceae) dengan kelimpahan yang jauh lebih sedikit sebanyak 120.000 sel/liter hanya dijumpai pada lokasi 3 (lokasi sampling paling timur). Hasil pengamatan Trichodesmium menggunakan mikroskop dengan berbagai perbesaran disajikan pada Gambar 4.

Tabel 2. Kelimpahan fitoplankton di lokasi sampling.

\begin{tabular}{lccccc}
\hline \multirow{2}{*}{ Organisme } & \multicolumn{5}{c}{ Lokasi sampling } \\
\cline { 2 - 6 } & 1 & 2 & 3 & 4 & 5 \\
\hline CYANOPHYCEAE & & & & & \\
Trichodesmium sp. & 558.480 .000 & 464.880 .000 & 49.920 .000 & 12.292 .800 .000 & 4.118 .400 .000 \\
BACILLARIOPHYCEAE & & & & & \\
Chaetoceros sp. & 0 & 0 & 120 & 0 & 0 \\
\hline Jumlah Taksa & 1 & 1 & 2 & 1 & 1 \\
Kelimpahan (sel/L) & 558.480 .000 & 464.880 .000 & 50.040 .000 & 12.292 .800 .000 & 4.118 .400 .000 \\
Indeks Keragaman & - & - & 0,02 & - & - \\
Indeks Keseragaman & - & - & 0,02 & - & - \\
Indeks Dominansi & 1 & 1 & 1 & 1 & 1 \\
\hline
\end{tabular}




\begin{tabular}{|c|c|c|c|c|c|}
\hline \multirow{2}{*}{ Organisme } & \multicolumn{5}{|c|}{ Lokasi sampling } \\
\hline & 6 & 7 & 8 & 9 & 10 \\
\hline \multicolumn{6}{|l|}{ CYANOPHYCEAE } \\
\hline Trichodesmium sp. & 11.169 .600 .000 & 670.800 .000 & 9.734 .400 .000 & 1.332 .800 .000 & 921.200 .000 \\
\hline \multicolumn{6}{|l|}{ BACILLARIOPHYCEAE } \\
\hline Chaetoceros sp. & 0 & 0 & 0 & 0 & 0 \\
\hline Jumlah Taksa & 1 & 1 & 1 & 1 & 1 \\
\hline Kelimpahan (sel/L) & 11.169 .600 .000 & 670.800 .000 & 9.734 .400 .000 & 1.332 .800 .000 & 921.200 .000 \\
\hline Indeks Keragaman & - & - & - & - & - \\
\hline Indeks Keseragaman & - & - & - & - & - \\
\hline Indeks Dominansi & 1 & 1 & 1 & 1 & 1 \\
\hline \multirow{2}{*}{ Organisme } & \multicolumn{5}{|c|}{ Lokasi sampling } \\
\hline & 11 & 12 & 13 & 14 & 15 \\
\hline \multicolumn{6}{|l|}{ CYANOPHYCEAE } \\
\hline $\begin{array}{l}\text { Trichodesmium sp. } \\
\text { BACILLARIOPHYCEAE }\end{array}$ & 58.464 .000 .000 & 188.160 .000 & 403.760 .000 & 2.175 .600 .000 & 70.560 .000 \\
\hline Chaetoceros sp. & 0 & 0 & 0 & 0 & 0 \\
\hline Jumlah Taksa & 1 & 1 & 1 & 1 & 1 \\
\hline Kelimpahan (sel/L) & 58.464 .000 .000 & 188.160 .000 & 403.760 .000 & 2.175 .600 .000 & 70.560 .000 \\
\hline Indeks Keragaman & - & - & - & - & - \\
\hline Indeks Keseragaman & - & - & - & - & - \\
\hline Indeks Dominansi & 1 & 1 & 1 & 1 & 1 \\
\hline
\end{tabular}
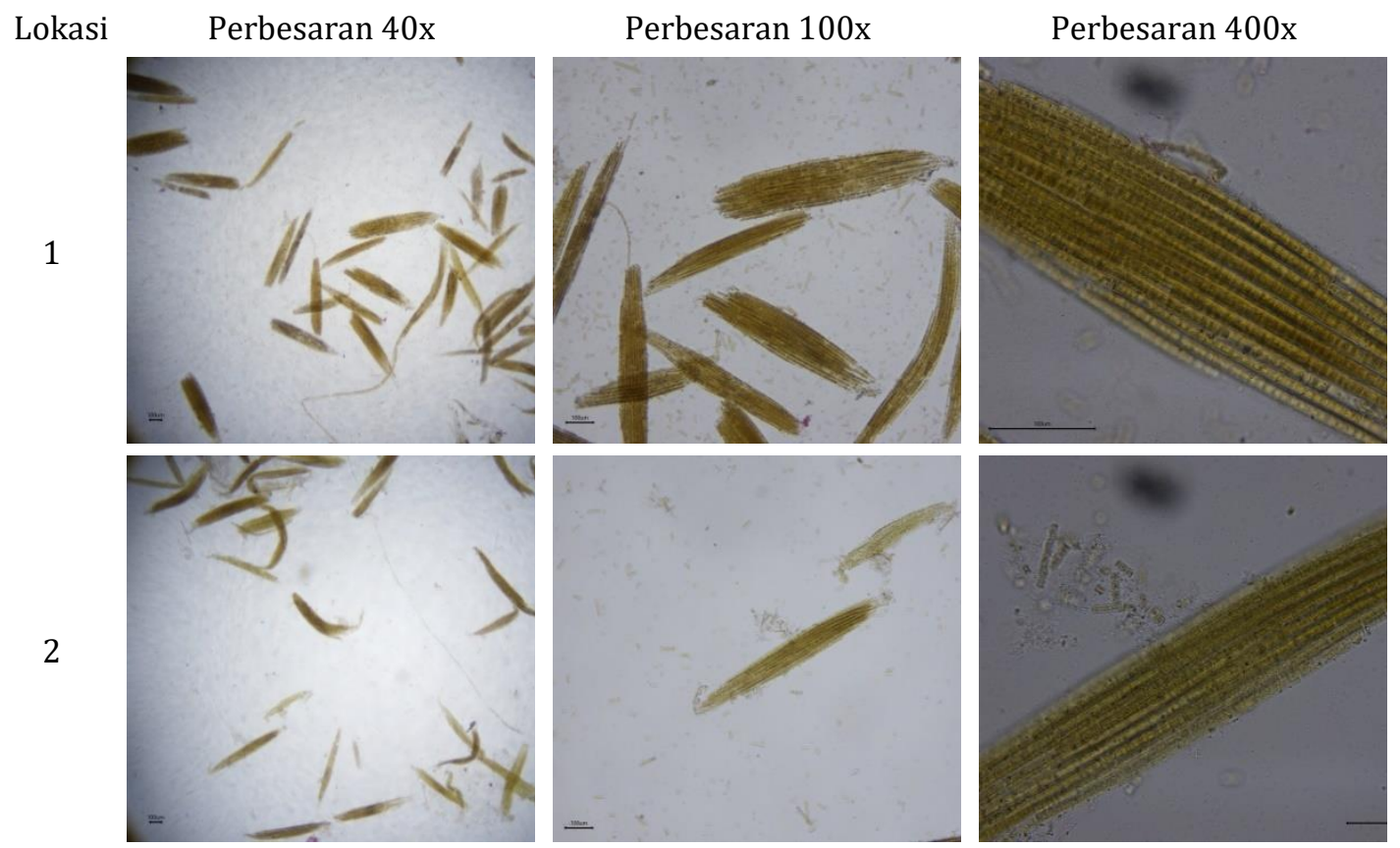

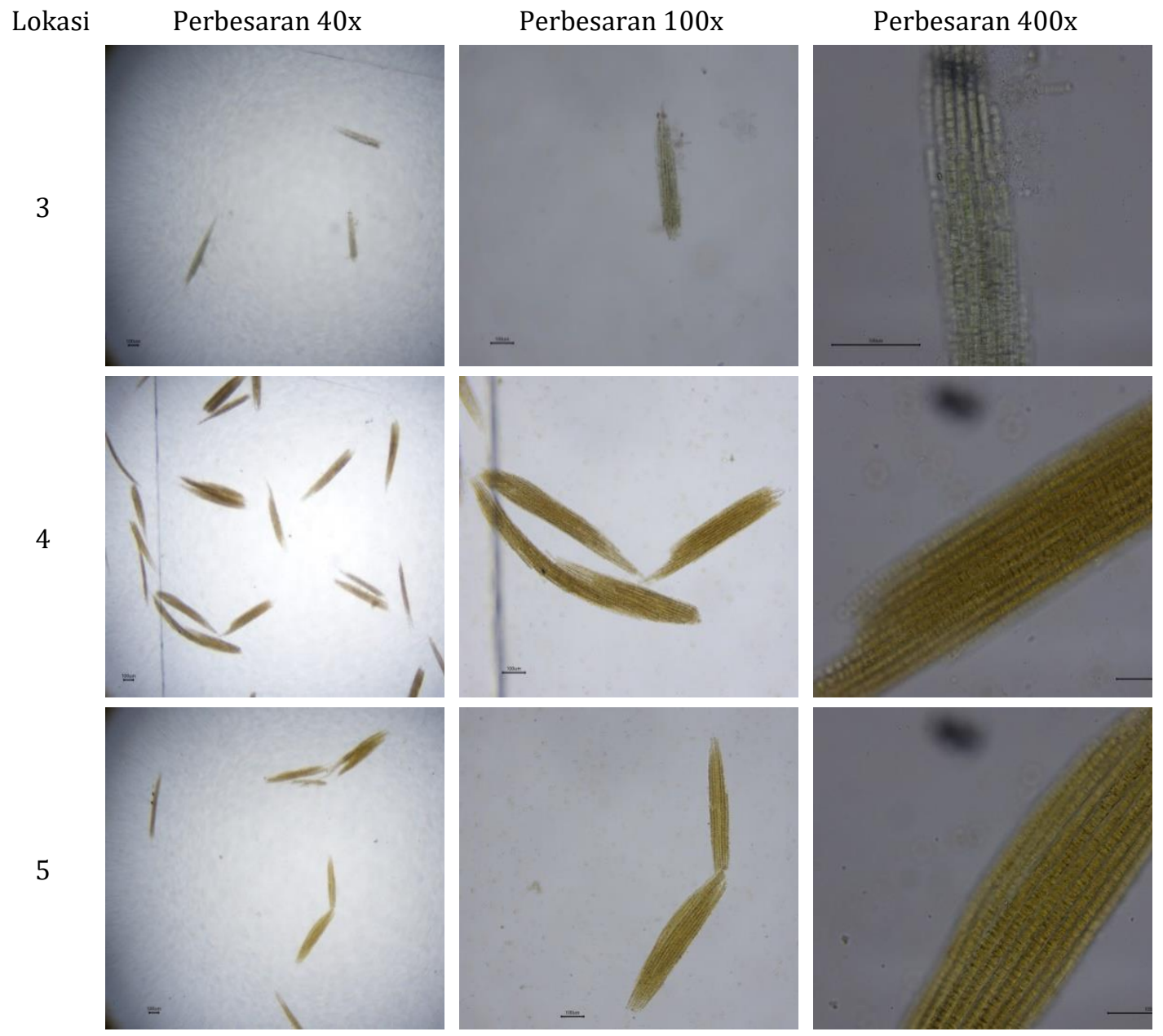

6
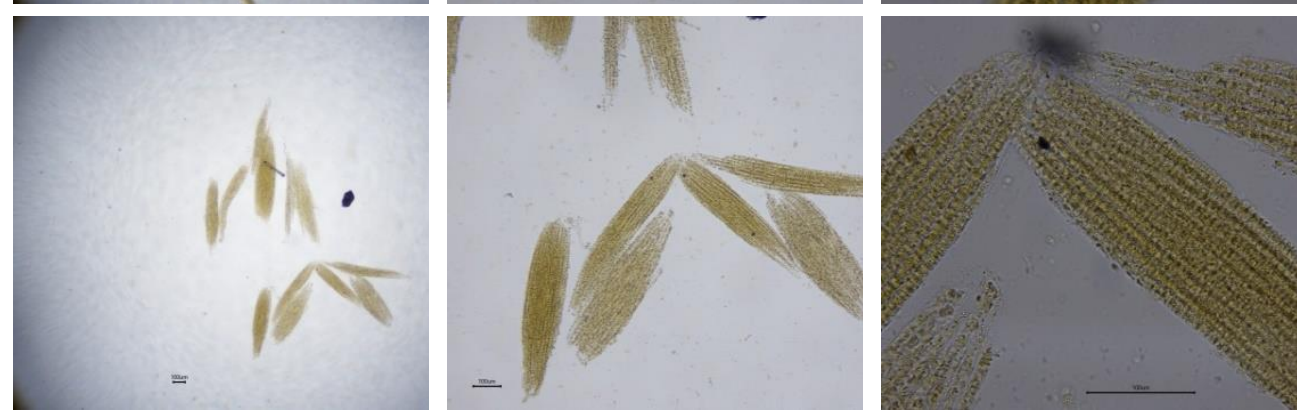

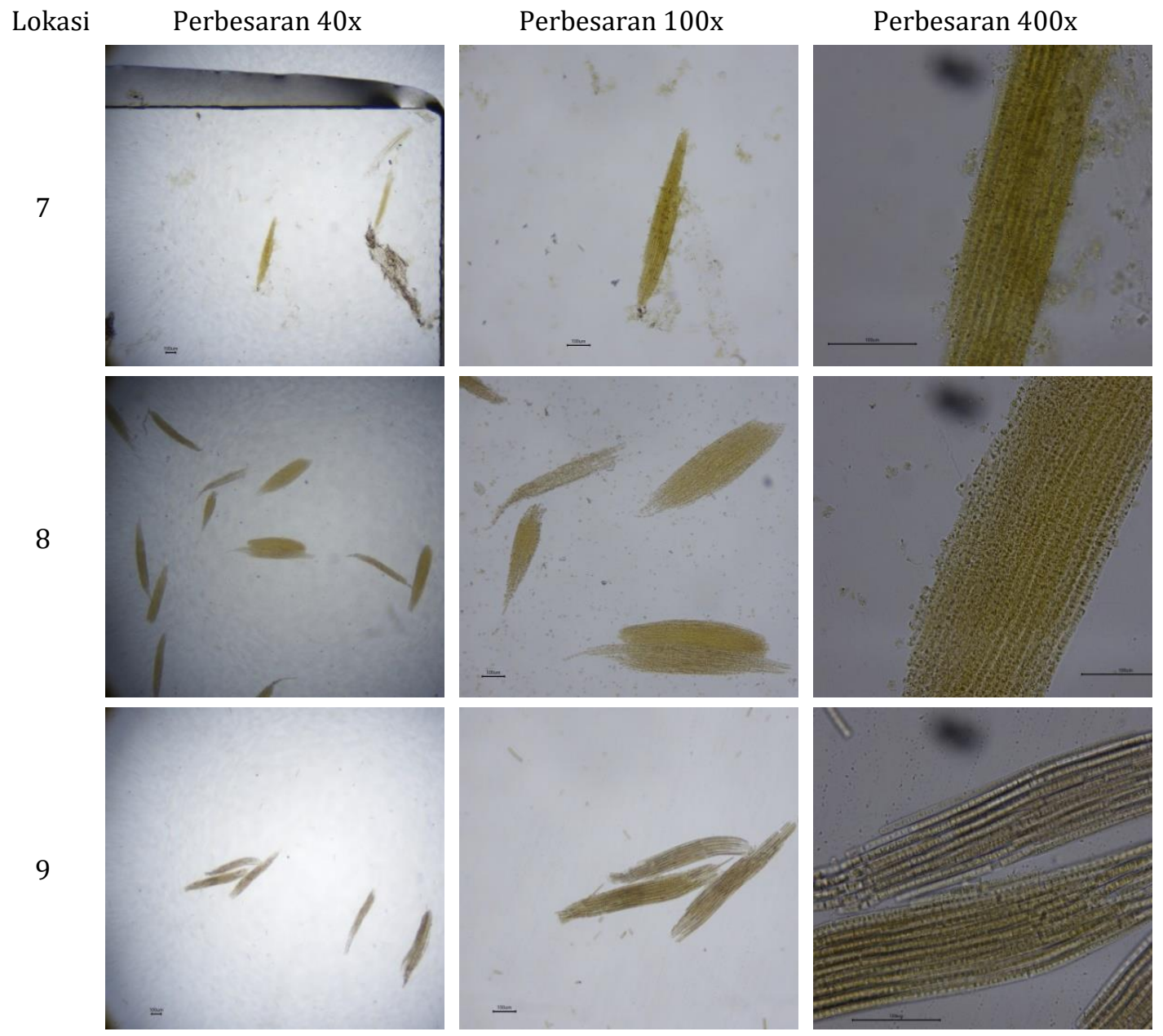

10
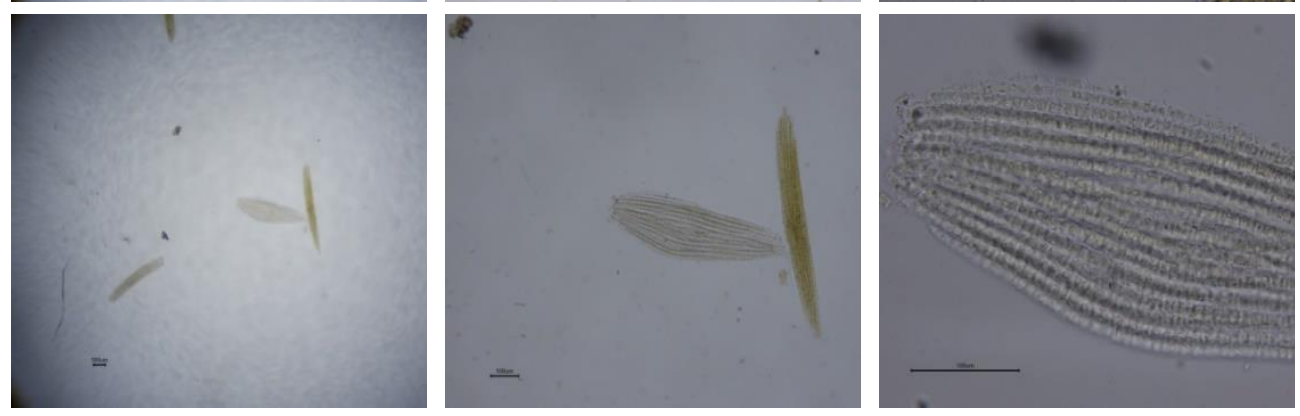

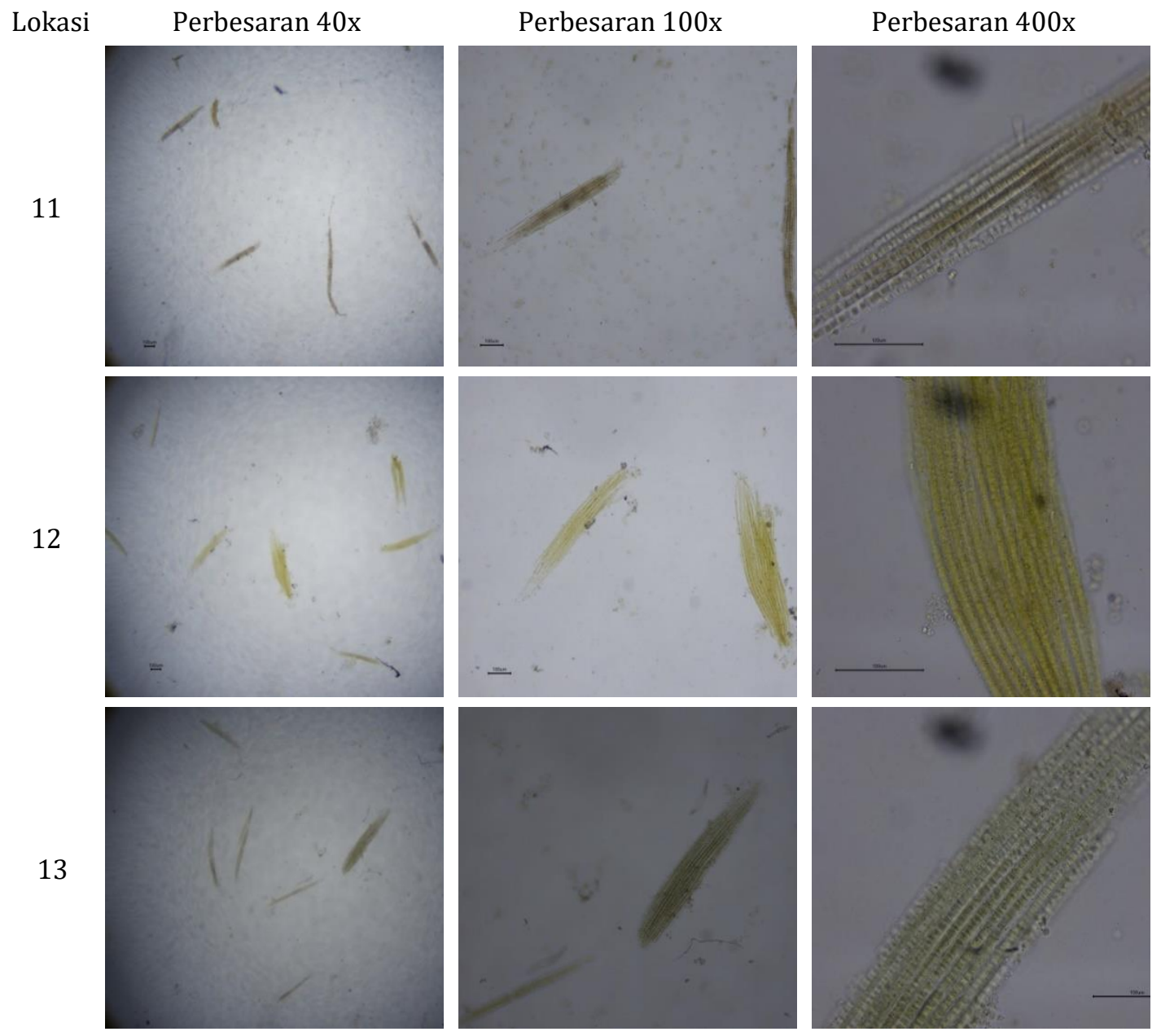

14
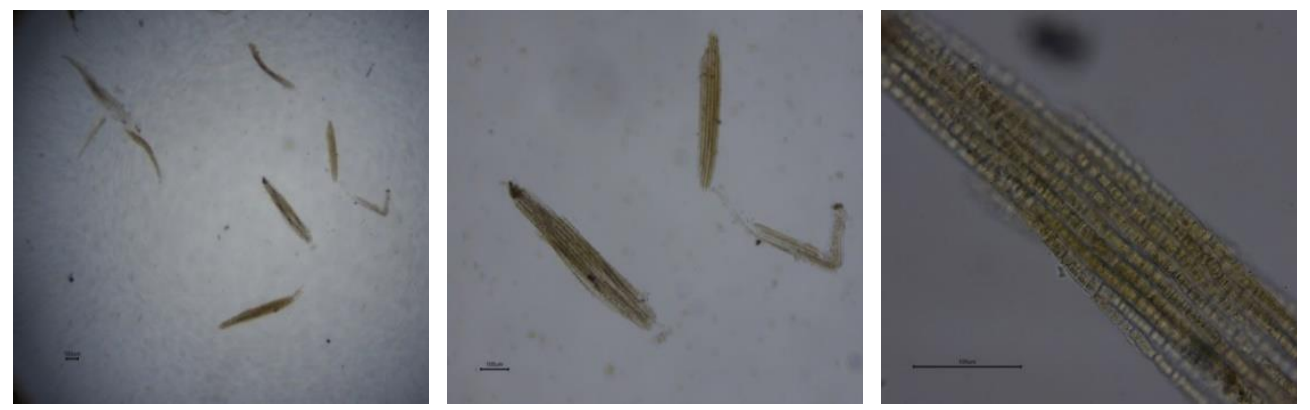

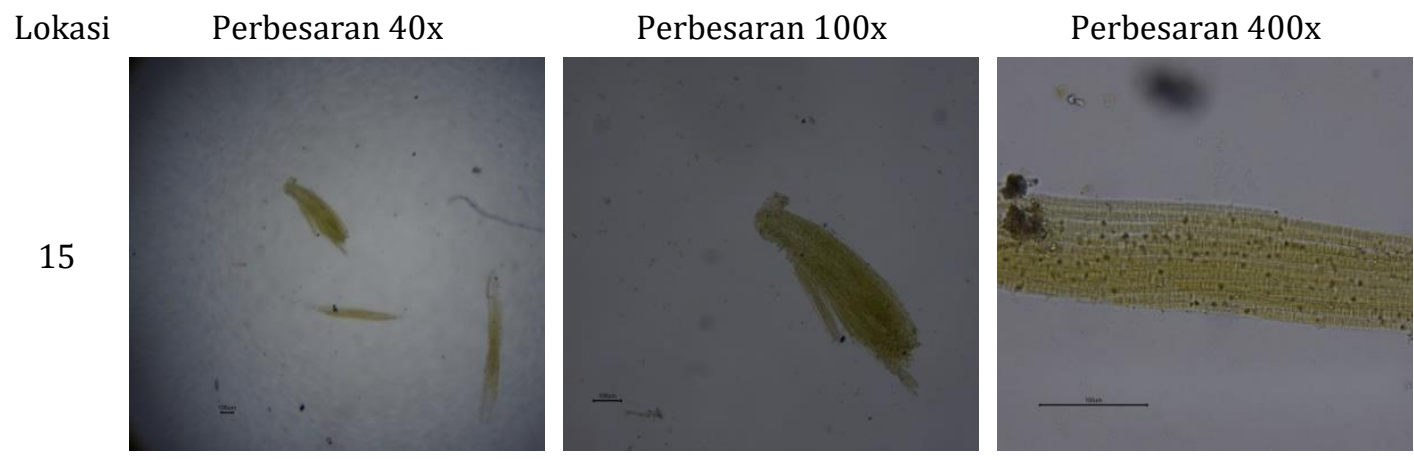

Gambar 4. Trichodesmium pada mikroskop dengan berbagai perbesaran.

Indikasi kejadian blooming ditentukan oleh kelimpahan fitoplankton yang

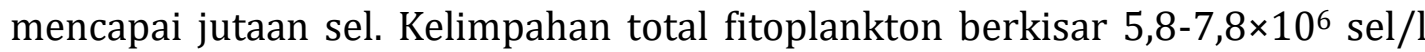
selama blooming yang didominasi oleh Cryptomonads and G. Instriatum, pada perairan estuari berturut-turut sebanyak 91,6\% dan 99,0\% (Egerton et al. 2014). Berdasarkan hasil analisis laboratorium, diketahui bahwa telah terjadi peningkatan populasi plankton secara berlebihan atau sering dikenal dengan istilah algae bloom. Fenomena ledakan populasi plankton dari Genus Trichodesmium pada perairan laut terutama di Indonesia telah teridentifikasi sejak lama. Laporan Rahav and Zeev (2017) menyebutkan bahwa di sebelah tenggara Laut Mediterrania juga terjadi pertumbuhan pesat Trichodesmium yang dipicu oleh peningkatan nitrogen dan fosfor di perairan dengan rasio 12:1. Selanjutnya, kejadian blooming Trichodesmium juga dilaporkan di Great Barrier Reef Australia, distimulir oleh peningkatan nutrien dari runoff daratan yang masuk ke laut (Blondeau-Patissier et al. 2018). Trichodesmium adalah salah satu jenis cyanobacterium yang sering mengalami pertumbuhan pesat di perairan pesisir India (Rajaneesh et al. 2020).

Thoha (1991) mengemukakan bahwa ledakan populasi Trichodesmium tercatat beberapa kali terjadi di Indonesia sejak tahun 1939-1991. Blooming pertama kali tercatat pada tahun 1939 di Selat Sunda dan Laut Jawa berdasarkan hasil penelitian Delsman, seorang pakar berkebangsaan Belanda. Delsman menjelaskan bahwa ledakan populasi Trichodesmium terjadi pada musim tertentu dan pada saat terjadinya blooming dapat dicirikan secara visual seperti kumpulan serbuk gergaji yang melayang di permukaan air. Beberapa kejadian blooming Trichodesmium yang pernah terjadi di sekitar perairan Pulau Seribu (Thoha 1991) dipaparkan sebagai berikut:

1. Puslitbang Oseanologi LIPI mengamati adanya blooming Trichodesmium pada 25-30 September 1991 di perairan Kepulauan Seribu, tepatnya di sebelah barat Pulau Pari. Kejadian berawal ketika air laut pasang sekitar pukul 07.00 WIB dan angin berhembus dari selatan ke utara. Perairan laut 
berwarna coklat muda dan setelah beberapa saat berubah menjadi semacam lendir, berbau busuk menyengat, dan menyebabkan perih di mata. Selama blooming, terjadi kematian ikan-ikan kecil, bintang laut, dan cacing laut.

2. Puslitbang Osenologi LIPI melaporkan blooming Trichodesmium pada 3 Oktober 1991 di antara Pulau Pari dan Pulau Panggang. Luas perairan yang mengalami ledakan populasi sekitar 15 mil laut, penampakan permukaan laut seperti serbuk gergaji berwarna hijau.

3. Pada 29 Oktober 2015 UPT Loka Pengembangan Kompetensi Sumber Daya Manusia Osenografi (UPT LPKSDMO) Pulau Pari menyampaikan informasi bahwa terjadi kondisi tidak normal pada perairan sisi selatan Pulau Pari, tampak seperti berminyak dan berwarna coklat keruh, berbau busuk, dan mengakibatkan kepala pusing. Pada 30 Oktober 2015 dtemukan sejumlah ikan mati, terapung, dan terdampar di pantai. Masyarakat dihimbau tidak mengambil dan mengkonsumsi ikan mati tersebut.

Peningkatan populasi plankton secara berlebihan dapat terjadi karena kondisi lingkungan perairan yang mendukung. Peningkatan populasi atau ledakan pertumbuhan plankton diakibatkan kandungan nutrien yang tinggi, khususnya nitrat dan ortofosfat. Ledakan populasi plankton dapat membahayakan kehidupan organisme lain di perairan karena mengakibatkan penurunan kandungan oksigen terlarut secara drastis di perairan.

Pada dasarnya fitoplankton memanfaatkan nutrien berupa nitrat sebagai bahan dasar asimilasi bahan organik yang menjadi sumber makanan primer bagi rantai makanan di laut. Konsentrasi nitrat yang dibutuhkan fitoplankton memiliki batas konsentrasi, jika nitrat di perairan melebihi kebutuhan fitoplankton maka dapat memicu terjadinya eutrofikasi, yang kemudian dapat memacu pertumbuhan mikroalga secara cepat (blooming). Salah satu jenis fitoplankton yang sensitif terhadap perubahan konsentrasi nitrat dan ortofosfat adalah Trichodesmium sp. Trichodesmium memiliki kemampuan memfiksasi nitrogen dalam bentuk ammonium (Tungka et al. 2016). Hasil analisis kualitas air laut (BOD, COD, ammonia, nitrit, nitrat, ortofosfat, pada lokasi terjadinya fenomena perairan coklat disajikan pada Tabel 3.

Kadar ammonia, nitrat, dan ortofosfat yang merupakan sumber nutrien bagi mikroalgae (fitoplankton) terukur cukup tinggi berkisar 0,551-361,344 $\mathrm{mg} / \mathrm{l}$ (ammonia), 0,423-25,556 mg/l (nitrat) dan 0,113-12,442 mg/l (ortofosfat). Kadar ketiga parameter ini tergolong sangat tinggi (Tabel 3). Menurut Rizqina et al. (2018), di Pulau Pari kadar nitrat berkisar 0,069-0,088 mg/l yang tergolong cukup optimal bagi pertumbuhan fitoplankton, sedangkan kandungan fosfat berkisar 0,004-0,006 mg/l. Hasil tersebut menunjukkan konsentrasi nitrat dan ortofosfat yang jauh lebih rendah dibandingkan penelitian ini. 
Tabel 3. Kualitas air laut di lokasi terjadinya blooming fitoplankton.

\begin{tabular}{|c|c|c|c|c|c|c|c|c|}
\hline \multirow{2}{*}{ No } & \multirow{2}{*}{ Parameter } & \multirow{2}{*}{ Satuan } & \multirow{2}{*}{ Baku mutu } & \multicolumn{5}{|c|}{ Lokasi sampling } \\
\hline & & & & 1 & 2 & 3 & 4 & 5 \\
\hline 1 & BOD5 & $\mathrm{mg} / \mathrm{l}$ & 20 & 1.100 & 1.300 & 16.000 & 20.000 & 19.000 \\
\hline 2 & COD & $\mathrm{mg} / \mathrm{l}$ & - & $5.215,19$ & $6.544,30$ & $85.063,29$ & $10.2151,90$ & $94.556,96$ \\
\hline 3 & Ammonia $\left(\mathrm{NH}_{3}-\mathrm{N}\right)$ & $\mathrm{mg} / \mathrm{l}$ & 0,3 & 79,546 & 74,897 & 154,153 & 207,720 & 361,344 \\
\hline 4 & Nitrat $\left(\mathrm{NO}_{3}-\mathrm{N}\right)$ & $\mathrm{mg} / \mathrm{l}$ & 0,008 & 1,438 & 16,091 & 16,58 & 7,474 & 4,904 \\
\hline 5 & Ortofosfat $\left(\mathrm{PO}_{4}-\mathrm{P}\right)$ & $\mathrm{mg} / \mathrm{l}$ & 0,015 & 2,538 & 0,438 & 0,239 & 11,199 & 6,290 \\
\hline 6 & Nitrit $\left(\mathrm{NO}_{2}-\mathrm{N}\right)$ & $\mathrm{mg} / \mathrm{l}$ & - & 0,466 & 0,409 & 0,514 & 4,569 & 2,684 \\
\hline \multirow{2}{*}{ No } & \multirow{2}{*}{ Parameter } & \multirow{2}{*}{ Satuan } & \multirow{2}{*}{ Baku mutu } & \multicolumn{5}{|c|}{ Lokasi sampling } \\
\hline & & & & 6 & 7 & 8 & 9 & 10 \\
\hline 1 & BOD5 & $\mathrm{mg} / \mathrm{l}$ & 20 & 18.000 & 6.600 & 15.000 & 2200,00 & 440,00 \\
\hline 2 & COD & $\mathrm{mg} / \mathrm{l}$ & - & $85.696,20$ & $31.455,70$ & $85.696,20$ & $11.202,53$ & $2.240,51$ \\
\hline 3 & Ammonia $\left(\mathrm{NH}_{3}-\mathrm{N}\right)$ & $\mathrm{mg} / \mathrm{l}$ & 0,3 & 266,339 & 284,532 & 237,030 & 3,250 & 22,086 \\
\hline 4 & Nitrat $\left(\mathrm{NO}_{3}-\mathrm{N}\right)$ & $\mathrm{mg} / \mathrm{l}$ & 0,008 & 2,733 & 25,556 & 24,453 & 2,865 & 0,469 \\
\hline 5 & Ortofosfat $\left(\mathrm{PO}_{4}-\mathrm{P}\right)$ & $\mathrm{mg} / \mathrm{l}$ & 0,015 & 11,510 & 2,063 & 4,549 & 12,442 & 0,126 \\
\hline 6 & Nitrit $\left(\mathrm{NO}_{2}-\mathrm{N}\right)$ & $\mathrm{mg} / \mathrm{l}$ & - & 1,439 & 2,826 & 3,929 & 0,404 & 0,112 \\
\hline \multirow{2}{*}{ No } & \multirow{2}{*}{ Parameter } & \multirow{2}{*}{ Satuan } & \multirow{2}{*}{ Baku mutu } & \multicolumn{5}{|c|}{ Lokasi sampling } \\
\hline & & & & 11 & 12 & 13 & 14 & 15 \\
\hline 1 & B0D5 & $\mathrm{mg} / \mathrm{l}$ & 20 & 5.500 & 400 & 650 & 900 & 440 \\
\hline 2 & COD & $\mathrm{mg} / \mathrm{l}$ & - & $25.443,04$ & $1.987,34$ & $3.240,51$ & $4.392,41$ & $2.101,27$ \\
\hline 3 & Ammonia $\left(\mathrm{NH}_{3}-\mathrm{N}\right)$ & $\mathrm{mg} / \mathrm{l}$ & 0,3 & 0,551 & 160,964 & 34,214 & 23,879 & 15,894 \\
\hline 4 & Nitrat $\left(\mathrm{NO}_{3}-\mathrm{N}\right)$ & $\mathrm{mg} / \mathrm{l}$ & 0,008 & 2,009 & 0,423 & 0,546 & 0,776 & 1,953 \\
\hline 5 & Ortofosfat $\left(\mathrm{PO}_{4}-\mathrm{P}\right)$ & $\mathrm{mg} / \mathrm{l}$ & 0,015 & 0,902 & 0,324 & 0,051 & 0,822 & 0,113 \\
\hline 6 & Nitrit $\left(\mathrm{NO}_{2}-\mathrm{N}\right)$ & $\mathrm{mg} / \mathrm{l}$ & - & 0,695 & 0,128 & 0,050 & 0,428 & 0,039 \\
\hline
\end{tabular}

Keterangan : Baku Mutu berdasarkan KepMenLH Nomor 51 Tahun 2004 (Baku Mutu Air Laut untuk Biota Laut ). Tanda (-) artinya parameter tidak memliki baku mutu.

Tingginya kadar ammonia, nitrat, dan ortofosfat juga diperkuat oleh tingginya nilai BOD dan COD yang menggambarkan tingginya keberadaan bahan organik di perairan yang diamati. Tingginya nilai BOD dan COD ini menggambarkan keberadaan bahan organik yang merupakan biomassa dari fitoplankton yang mengalami blooming. COD jauh lebih tinggi nilainya dibandingkan BOD, karena COD menggambarkan tidak hanya bahan organik yang bisa didegradasi secara biologis, tetapi juga bahan organik yang sukar didegradasi secara biologis (Gambar 5).

Terlihat tendensi semakin tinggi kadar ortofosfat diikuti dengan tingginya kelimpahan fitoplankton (Tabel 4 dan Gambar 6). Namun demikin hubungan antara nitrat dengan kelimpahan fitoplankton tak memperlihatkan pola yang selaras (Tabel 5 dan Gambar 7). Penelitian Cunha and Calijuri (2011), Wu et al. (2019) menyebutkan bahwa fosfat adalah salah satu faktor pembatas pertumbuhan fitoplankton. 


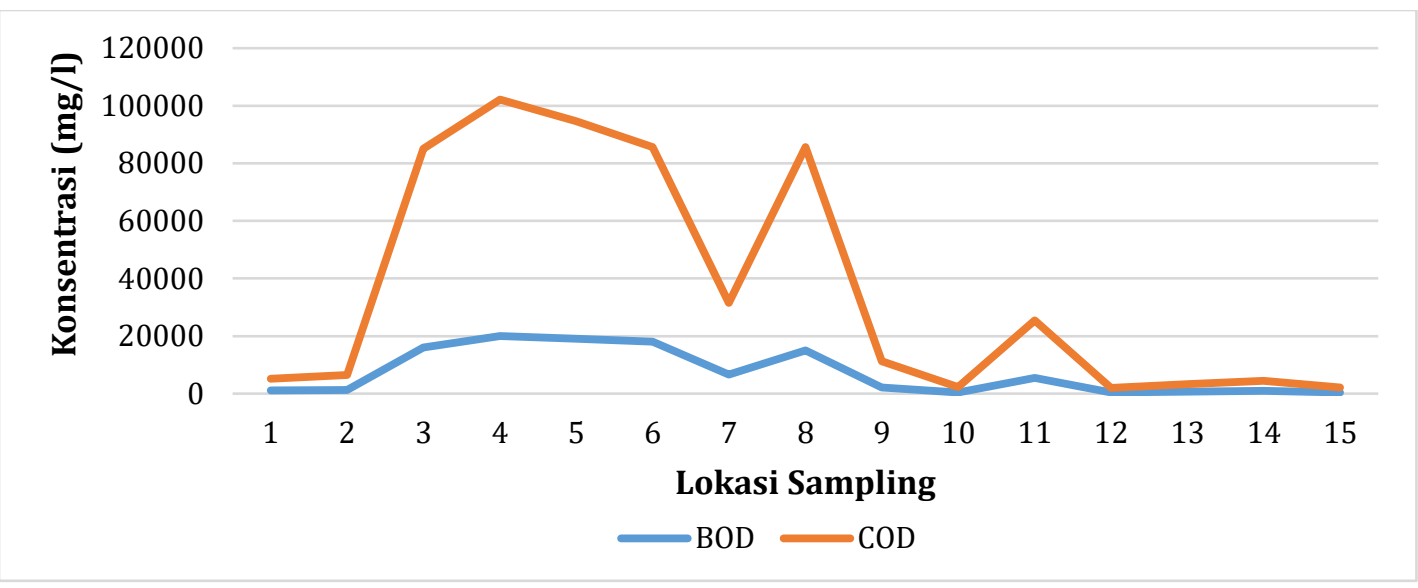

Gambar 5. Perbandingan nilai BOD dan COD.

Tabel 4. Perbandingan konsentrasi ortofosfat dan kelimpahan plankton.

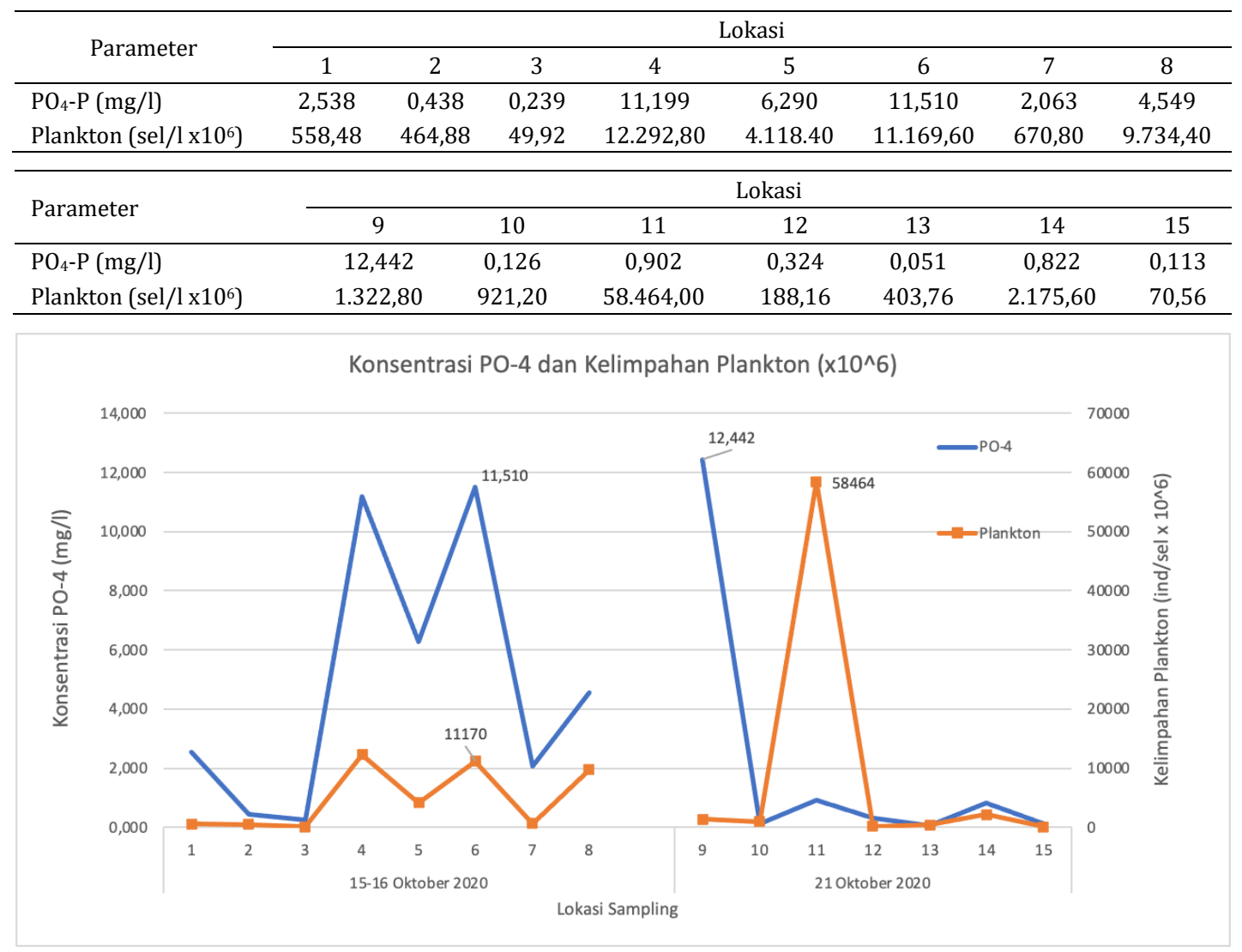

Gambar 6. Grafik perbandingan konsentrasi ortofosfat dan kelimpahan plankton. 
Tabel 5. Perbandingan konsentrasi nitrat dan kelimpahan plankton.

\begin{tabular}{|c|c|c|c|c|c|c|c|c|c|}
\hline \multirow{2}{*}{ Parameter } & \multicolumn{9}{|c|}{ Lokasi } \\
\hline & 1 & 2 & & 3 & 4 & 5 & 6 & 7 & 8 \\
\hline $\mathrm{NO}_{3}-\mathrm{N}(\mathrm{mg} / \mathrm{l})$ & 1,438 & 16,0 & & 16,580 & 7,474 & 4,904 & 2,733 & 25,556 & 24,453 \\
\hline $\begin{array}{l}\text { Plankton } \\
(\text { sel/l x106) }\end{array}$ & 558,48 & 464,8 & & 49,920 & $12.292,800$ & 4.118 .400 & $11.169,600$ & 670,800 & $9.734,400$ \\
\hline \multirow{2}{*}{ Parameter } & \multicolumn{9}{|c|}{ Lokasi } \\
\hline & \multicolumn{2}{|c|}{9} & \multicolumn{2}{|c|}{10} & 11 & 12 & 13 & 14 & 15 \\
\hline $\mathrm{NO}_{3}-\mathrm{N}(\mathrm{mg} / \mathrm{l})$ & \multicolumn{2}{|c|}{2,865} & \multicolumn{2}{|c|}{0,469} & 2,009 & 0,423 & 0,546 & 0,776 & 1,953 \\
\hline $\begin{array}{l}\text { Plankton } \\
(\text { sel/l x106) }\end{array}$ & \multicolumn{2}{|c|}{$1.322,800$} & \multicolumn{2}{|c|}{921,200} & $58.464,000$ & 188,160 & 403,760 & $2.175,600$ & 70,560 \\
\hline
\end{tabular}

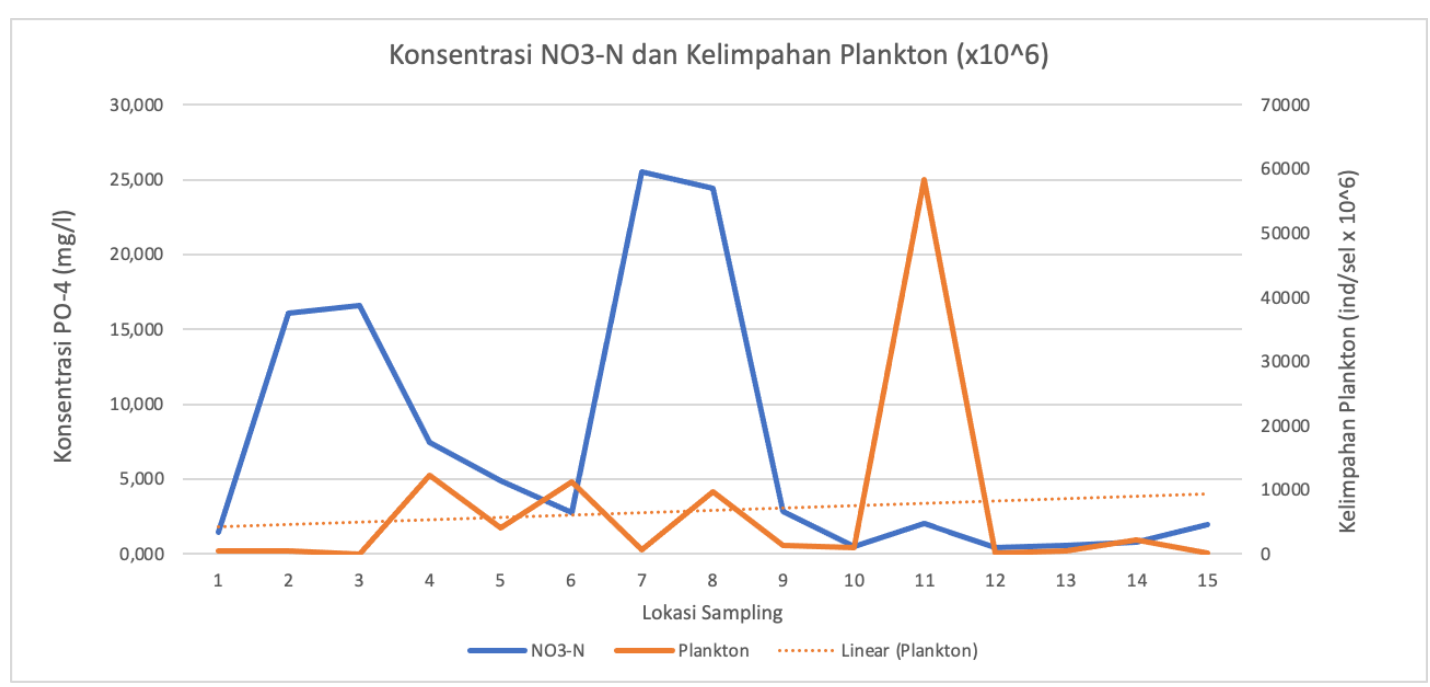

Gambar 7. Grafik perbandingan konsentrasi nitrat dan kelimpahan plankton.

Penelitian pada 2014, 2015, dan 2016 di Teluk Jakarta menyebutkan bahwa jenis fitoplankton yang dominan pada kejadian blooming adalah Skeletonema costatum, Pseudonitzschia spp, and Noctiluca scintillans (Damar et al. 2021). Laporan lain di lokasi yang sama menyebutkan bahwa kelimpahan fitoplankton saat blooming berkisar 40,0-1699,1×106 $\mathrm{sel} / \mathrm{m}^{3}$. Jenis yang dominan adalah Skeletonema, Chaetoceros dan Thalassiosira (Sidabutar et al. 2016).

Sementara itu, pada kejadian blooming lainnya di Teluk Jakarta, justru Dinoflagellata yang mendominasi dengan urutan kelimpahan adalah Noctiluca > Ceratium > Gonyaulax > Gymnodinium > Dinophysis. Rentang kelimpahan Dinoflagellata terendah sebesar $353.857 \mathrm{sel} / \mathrm{m}^{3}$ (Dinophysis) dan tertinggi sebesar $85.279 .547 \mathrm{sel} / \mathrm{m}^{3}$ (Noctiluca) (Nasution et al. 2021). Penelitian lain di perairan pesisir Demak menemukan dua kelas fitoplankton sebagai penyebab Harmful Algal Bloom (HAB) yaitu Bacillariophyceae dan Dinophyceae dengan jumlah sebanyak 9 genus (Gurning et al. 2020). 


\section{KESIMPULAN}

Fenomena yang terjadi di sekitar Sumur Zulu merupakan kejadian ledakan populasi (algae bloom) fitoplankton Trichodesmium. Fenomena tersebut telah terjadi sejak lama dan berulang di perairan Kepulauan Seribu. Hal ini berkaitan erat dengan perubahan musim dan peningkatan kandungan unsur hara di perairan, khususnya nitrat dan ortofosfat, yang mendukung terjadinya pertumbuhan fitoplankton secara pesat (blooming).

\section{UCAPAN TERIMA KASIH}

Dihaturkan terima kasih kepada PHE ONWJ yang telah memfasilitasi penelitian ini.

\section{DAFTAR PUSTAKA}

Al-Azri AR, Al-Hashmi KA, Al-Habsi H, Al-Azri N and Al-Khusaibi S. 2015. Abundance of harmful algal blooms in the coastal waters of Oman: 20062011. Aquatic Ecosystem Health \& Management 18(3):269-281.

Cunha DGF and Calijuri MDC. 2011. Limiting factors for phytoplankton growth in subtropical reservoirs: the effect of light and nutrient availability in different longitudinal compartments. Lake and Reservoir Management 27(2):162-172.

Damar A, Prismayanti AD, Rudianto BY, Ramli A and Kurniawan F. 2021. Algae bloom phenomenon in Jakarta Bay as symptoms of severe eutrophication: monitoring results of 2014-2016. IOP Conf. Series: Earth and Environmental Science 744 (2021) 012009.

Egerton TA, Morse RE, Marshall HG and Mulholland MR. 2014. Emergence of algal blooms: the effects of short-term variability in water quality on phytoplankton abundance, diversity, and community composition in a tidal estuary. Microorganisms 2(1):33-57.

Gurning LFP, Nuraini RAT dan Suryono. 2020. Kelimpahan fitoplankton penyebab harmful algal bloom di perairan Desa Bedono, Demak. Journal of Marine Research 9(3):251-260.

KepMenLH (Keputusan Menteri Lingkungan Hidup) Nomor 51 Tahun 2004 tentang baku mutu air laut.

Nasution AK, Takarina ND and Thoha H. 2021. The presence and abundance of harmful dinoflagellate algae related to water quality in Jakarta Bay, Indonesia. Biodiversitas 22:2909-2917.

Blondeau-Patissier D, Brando VE, Lønborg C, Leahy SM and Dekker AG. 2018. Phenology of Trichodesmium spp. blooms in the Great Barrier Reef lagoon, 
Australia, from the ESA-MERIS 10-year mission. PLoS ONE 13(12) e0208010. https://doi.org/10.1371/journal.pone.0208010.

Rahav E and Bar-Zeev E. 2017. Sewage outburst triggers Trichodesmium bloom and enhance $\mathrm{N}_{2}$ fixation rates. Scientific Reports 7(4367). https://doi.org/ 10.1038/s41598-017-04622-8.

Rajaneesh KM, Naik RK, Roy R and D'Costa PM. 2020. Chapter 3 - cyanobacteria in tropical and subtropical marine environments: bloom formation and ecological role. In: Singh PK, Kumar A, Singh VK, Kumar AK. 2020. Advances in Cyanobacterial Biology. Academic Press. London.

Rizqina C, Sulardiono B dan Djunaedi A. 2018. Hubungan antara kandungan nitrat dan fosfat dengan kelimpahan fitoplankton di perairan Pulau Pari, Kepulauan Seribu. Management of Aquatic Resources Journal 6(1):43-50.

Sidabutar T, Bengen, DG, Wouthuyzen S and Prartono T. 2016. The abundance of phytoplankton and its relationship to the N/P ratio in Jakarta Bay, Indonesia. Biodiversitas 17:673-678.

Thoha H. 1991. Ledakan populasi Trichodesmium erythraeum. Oseana XVI(3):915.

Tungka AW, Haeruddin dan Ain C. 2016. Konsentrasi nitrat dan ortofosfat di muara sungai banjir kanal barat dan kaitannya dengan kelimpahan fitoplankton harmful alga blooms (HABs). Saintek Perikanan : Indonesian Journal of Fisheries Science and Technology 12(1):40-46. https://doi.org/ 10.14710/ijfst.12.1.40-46.

Wu Z, Liu J, Huang J, Cai Y, Chen Y and Li K. 2019. Do the key factors determining phytoplankton growth change with water level in China's largest freshwater lake?. Ecological Indicators 107 (2019) 105675. 